\title{
Comparative Study on the Growth and Yield of Pleurotus Ostreatus Mushroom on Lignocellulosic by- Products
}

\author{
Zahida Nasreen*, Sakhawat Ali, Shumaila Usman, Saima Nazir, Ammara Yasmeen \\ Biotechnology and Food Research Centre, PCSIR Labs Complex, Lahore 54600, Pakistan.
}

\begin{abstract}
The edible mushroom Pleurotus ostreatus has been studied as a potential crop to reduce agricultural solid wastes and increase mushroom production. P. ostreatus cultivated on various agricultural wastes singly i.e. rice straw $(R S)$, rice husk $(R H)$ wheat straw $(W H)$, barley straw $(B S)$, and cotton wastes $(C W)$. The biological efficiency (B.E) was 25.61, 9.51, 22.6, 21.628 and $25.78 \%$ while rounding up the total weight of fruit yield $1.0 \mathrm{~kg}$ substrate was 258.04, 125.0, 226.0, 198.0 and 257.0 gms (on fresh wt. Basis), when grown on $R S, R H, W S, B S$ and $C W$. The percentage of biomass loss from each substrate was 29.79, 16.89, 38.023, 30.0 and $33.40 \%$. Respectively, all the aforementioned wastes treated with P. ostreatus exhibited losses primarily in cellulose, hemicellulose, lignin, and fiber components after the harvest of P. ostreatus. The crude and soluble protein contents were enhanced by the incubation of the mushroom probably due to the addition of microbial protein. The losses of lignin and cellulose were higher in RS followed by $C W, W S$, and BS. Treated agro wastes with $1.25 \%$ acid and base enhanced biodegradation ability and mycelial growth of the mushroom. Comparatively, loss of lignin, cellulose, hemicellulose and crude fiber is higher in treated then the untreated substrates. Similarly by the addition of chickpea powder as nitrogen source improved the growth pattern and metabolic activity of the P. ostreatus.
\end{abstract}

Keyword: Agricultural wastes, Pleurotus ostreatus, nitrogen source, Biodegradation.

\section{INTRODUCTION}

Mushrooms are fleshy saprophyte fungi and it found growing on damp rotten log of wood trunk of trees, decaying organic matter and in damp soil rich in organic substances. Edible mushrooms are highly nutritious and can be compared with eggs, milk and meat (Mata et al 2005).The content of essential amino acids in mushroom is high and close to the need of the human body. Mushroom is easily digestible and it has no cholesterol content.

The Oyster mushroom belongs to the genus Pleurotus. They have a high saprophytic colonizing ability and can grow on virtually and agricultural waste. They rank among the top six mushrooms produced in the world. The consumption and production of edible mushrooms in developing countries have occurred for many years, but there has been an up surge of interest in cultivation of Oyster mushroom in the last decade as it is relatively easy to grow. Because of their spicy flavor and their medical effects in reducing plasma cholesterol these are widely consumed in Europe, China USA and Japan.

Cultivation of Pleurotus sp. reaches to the second largest in amount after Agaricus bisporus. Recently then being a growing interest in Pakistan to cultivate them on different readily available agricultural wastes (Hassan, et al 2011). Although, almost every kind of lignocelluloses are likely to be used as substrate for the cultivation of Pleurotus sp., the main and co- substrate differ among countries and even regions based on available abundance and lower prizes (Belewu, 2003).

However, the cultivation of mushroom is still very limited and the industry is still at its infancy in Pakistan (Kausar and Bajwa, 2005; Randive, 2012). The major problems associated with the transfer of technology for mushroom cultivation is the lack of technical know-how for its cultivation. The cultivation of edible mushroom using agricultural residues such as rice straw, rice husk, wheat straw, barley straw, banana leaves, cotton waste, corn cob, ground nut shell, saw dust and cassava peel is a process to convert these materials, which are otherwise considered to be wastes, into value added human foods (Abena, et al 2015).The present study describes utilization of abundantly available agricultural wastes i.e. rice straw, rice husk, wheat straw, barley straw and cotton wastes for the 
cultivation of oyster mushroom. $P$. ostreatus mycelia grew very well on wide range of these cellulose wastes. RS, RH, WS, BS as well as $\mathrm{CW}$ all supported good growth and fast mycelia extension of the mushroom.

During an investigation for the cultivation of mushroom on agricultural residues, it was found that rice straw, wheat straw, sawdust, cotton waste, barley straw, and bagasse were suitable substrates for the cultivation of edible mushrooms (Wenjie, et al 2013).

The aim of this study is to cultivate the P. ostreatus on different agricultural wastes which would there after minimize the pollution problems created due to the agricultural wastes. Utilization of low cost agro wastes for valuable end product will lead to develop low cost cultivation technology for rural community, which in turn would be a step forward to elevate poverty in Pakistan. Bhatti et al (2007).

\section{Material AND Method}

Establishing mycelial culture and spawn: To establish the mycelial culture of the mushroom Potato dextrose agar (PDA) medium was employed. The mycelium from PDA slant was used for spawn production. Sorghum and barley grains were washed in water and boiled 15 minutes. The boiled grains then placed on a sieve to drain, after which they were spread on a clean plastic sheet to dray. These grains were impregnated by calcium carbonate; these coated grains were kept in a well cleaned and drained jam jar. The jars were covered with cotton plugged and latter autoclaved at $121^{\circ} \mathrm{C}$ for 20 minutes after which jars were cooled at room temperature. The cooled spawn of P.ostreatus was distributed evenly over the surface. The jars were then incubated at $25 \pm 1^{\circ} \mathrm{C}$ in a ventilated incubator for 8 to 12 days. Each jar was shaken thoroughly by hand periodically to distribute the mycelia to the grains.

\section{Experiment}

Preparation of the substrates and their spawning: The substrates included wheat straw, barley straw, paddy straw and rice husk and cotton waste. The wheat straw, barley and paddy straw and rice husk were obtained from the agricultural farm of Seihkupura, cotton waste was procured from local market. Every fresh substrate was dried before any degradation process throughout the study. Paddy, barley and wheat straw were chopped into 5 to $8 \mathrm{~cm}$ long pieces, paddy husk and cotton wastes were used as such. Each substrate was then soaked in water for $24 \mathrm{~h}$ separately, for moisture absorption and tendering. The substrates were then placed on wire sieves to drain.

The moist substrate were fortified with nitrogen supplement i.e. chick pea powder at $4 \%(\mathrm{w} / \mathrm{w})$ of the dry weight of the respective substrate. After fortification, the substrates were divided in to $200 \mathrm{~g}, 300 \mathrm{~g}$, and $1 \mathrm{~kg}$ lots. These substrates were packed in separate transparent polyethylene bags (heat resistant). $10 \mathrm{bags}$ of each substrate were prepared. The substrates were autoclaved at $121 \mathrm{oC}$ for 20 minutes. After autoclaving, the substrates were cooled to room temperature. The spawn of P. ostreatus was distributed consistently over the surface of the substrates. The spawn was added at $2 \%(\mathrm{w} / \mathrm{w})$ of the substrate in each case.

\section{Experiment}

All the aforementioned agro wastes were treated with $1.25 \%$ sodium hydroxides or sulphuric acid. Clean and dried agro wastes were socked in $1.25 \%$ alkali or acid overnight separately, after soaking each material was washed thoroughly with tap water followed by double distilled water until it become neutral ( $\mathrm{pH} 7) .150 \mathrm{~g}, 200 \mathrm{~g}$ and $300 \mathrm{~g}$ of each substrate was filled in polythene bags $(8 \times 12$ and $9.5 \times 7$ inches) after adjusting the moisture contents. All the bags were autoclaved at $121 \mathrm{oC}$ for 20 minutes. Each bag was aseptically inoculated with $2 \%(\mathrm{w} / \mathrm{w})$ spawn. A plastic pipe with cotton plugs was introduced in all bags for ventilation. All bags were incubated in the incubator at $25+10 \mathrm{C}$ for 22 days.

Spawn running and fructification: The bags containing spawned substrates were placed on shelves in a disinfected spawn running / fructification room had a concrete floor. The spawn running room was kept humid by pouring / sprinkling of water every day on the floor. The humidity, temperature and light of the spawn running room were monitored daily. Substrates were subjected to fructification conditions when time taken to reach this stage was the mycelium had sufficiently colonized, $18 \mathrm{~d}$ on paddy straw and cotton waste, $19 \mathrm{~d}$ on barley straw and $20 \mathrm{~d}$ on wheat straw and bagasse. The spawn running longer then $22 \mathrm{~d}$ resulted in mycelial degeneration (i.e. hyphae collapsed and patches of 
substrates become visible again. Fructification conditions included opening of bags to provide more light and ventilation). Under these condition two days were allowed for pin head formation. Temperature in the spawn running room was monitored 24-26 oC along with relative humidity of 73$78 \%$ and light at only $1.01 \mathrm{~m} / \mathrm{sqf}$ provided by cool white fluorescent lights.

Harvesting of fruiting bodies and comparison of biological efficiencies on different substrates: Fruiting bodies were harvested when it completely mature (2-3 days of emerging). The substrates were incubated under the same conditions for another 7 days after each harvesting for second and third flushes. Mushroom from different substrates and treatments were kept separately for fresh weight measurements. The biological efficiencies (B.E) were calculated following (Khare, et al 2010).

Extend of utilization of substrate was determined by the following methods: Analysing of the substrates before spawning and after harvesting. The parameters of analysis included: Moisture, dry matter, ash content, fat, protein, soluble protein, crude fiber, lignin, cellulose and hemi cellulose of the substrates.

All samples were dried for $24 \mathrm{~h}$ in an oven at $105 \mathrm{oC}$. They were then ground and sieved through 5 $\mathrm{mm}$ mesh. Each sample was stored separately in dry and clean bottle with airtight lid in a refrigerator until analyzed.

Substrates fiber was analyzed according to Goering and Van Soest (1970). Fiber content was determined by analyzing the acid- detergent fraction (ADF), which is the lignocellulosic fraction of the substrate, followed by analyzing the neutral detergent fraction (NDF), which includes lignin, cellulose and hemi cellulose fractions of the substrate. The hemi cellulose content of the substrate then is obtained by subtracting ADF from NDF. Lignin and cellulose content of the substrate were determined according the methods of Kurschner (1930) and ASTM (1961). The total substrate nitrogen content was determined according to Markham (1942).

Statistical analysis. Mean values of parameters studied were analyzed by the Duncan Multiple Range Test (DMR) (Steel and Torrie 1980).

\section{RESULTS AND DisCUSSION}

Of the five substrates used, the highest mushroom fresh weights were produced on rice straw followed by cotton waste supplement with $4 \%$ organic nitrogen i.e. chickpea powdered (CP) as nitrogen source (Fig. 1 and Table lll).

RS and CW gave appreciable yield of the mushroom mycelium. This result agrees with the report of Fasidi (1996). He reported that rice straw, wheat straw, cotton waste and rice husk as the natural substrate on which Volvariella esculenta grew very well. RS and CW are good for the production of P. ostreatus because of this richness in vitamins which are good stimulants for high mushroom yield. WS and BS were also best for P. ostreatus growth (Rana, et al 2007). Similarly; the highest number of fruiting bodies per bag was recorded on rice straw and cotton wastes (Fig 2). An average of 258.04320.92 , 257-326.64 $\mathrm{g}$ fresh weight mushrooms were harvested per $1 \mathrm{~kg}$ of dry weight substrates (RS \& CW). The number of fruit bodies was 74-113, 72-108 per bag. (RS \& CW) (Table-1 \& Fig-11) The biological efficiency (B.E) was 25.61-32.69 and 25.78-32.05\% (Table-1 \& Fig 11l).

Wheat straw supplement with $4 \%$ chick pea powder was the second best harvest (Table- 111). An average of 226-286 $\mathrm{g}$ fresh weight mushroom was harvested per $\mathrm{kg}$ dry weight substrate in this treatment and the B.E was $22.6-28.60 \%$ and no. of fruit bodies was 59-78 (Fig 1, $11 \& 111$ ). Whereas the third best harvest was obtained on barley straw with $4 \%$ chick pea powder as the nitrogen supplement (198-226.932 g; B.E 21.628 -26.69\%) (Fig. 111 \& 1ll, Table 1and 1ll). Likewise, in case of rice husk waste the average fresh weight of the mushrooms was 125-15039 g per kg dry weight substrates (B.E 9.51-15.04 \%),(Table-1 \& Fig 111). The number of fruit bodies was 37-51. It was also noted that the no. of fruit bodies, mycelial growth, B.E was less in unfortified substrates as compared to fortified and treated substrates in each case.

Mycelia covered the RS in about 15 days while full colonization was observed within 20 days in both RS and CW. On the other hand complete colonization of mycelia occurred after 22-24 days in case of WS, BS and RH. Maximum growth was estimated from the rice straw and cotton waste (Table- 1). The higher yield on RS and CW appeared to be due comparatively better availability of nitrogen and carbon from these substrates. So, RS and CW are recommended as best substrates for the cultivation 
of Oyster mushroom which is in agreement with the finding of Hami (1990), who studied the Oyster mushroom cultivation on sawdust and found that P. ostreatus gave the maximum yield on these wastes. It also observed that when P. ostreatus grow on rice husk its mycelia yield is comparatively lower than other wastes (Table $11,111 \mathrm{lV} \& \mathrm{~V}$ ). The lower yield on RH was due to the presence of silica compounds is another reason which makes the husk more resistant to fungal attack through their enzymic system (Chang, 1988). The lower yield on RH was also due to the growth of saprophytic moulds.

The crop of P. ostreatus was harvested in three flushes. The maximum yield was obtained in first flush than the second and the third flush. This study agreed with the observation of Oei (2003) for Volvariella esculenta.

There was a reduction in the weight of the wastes used as substrate and this shows that the P. ostreatus has the ability to degrade lignocellulosic material during the idiophase stage followed by severe nitrogen and carbon depletion (Manson, et al 1989). Biomass losses in rice straw, rice husk, wheat straw, barley straw, and cotton waste were $(29.79-51.7,16.89-24.07,38.023-48.86,30.0-35.34$, and $33.40-50.79 \%$ ) respectively, (Fig-1) which showed that degradation and solubilization of biomass was intense in case of each agricultural waste (Table 1l, $111,1 \mathrm{~V} \& \mathrm{~V}$ ). The crude and soluble protein, crude fiber, cellulose, hemicellulose and lignin contents of the untreated waste were different from the treated once, which is in agree with the report of Mata (2005).The crude and soluble protein contents of the substrate treated and fortified agro wastes were significantly higher than untreated sample, due probably to the addition of fungal protein during solubilization and degradation (Table 11111 \& IV). This agrees with the report of Jacqueline and Visser, (1996) who reported that the extra cellular enzymes secreted by the fungus contain amorphous homo and hetro polysaccharides which are often in association with fungal protein. The protein contents of the fungus untreated, treated and nitrogen supplemented samples increased from RS 7.07-9.418,8.46 and 13.38, RH 5.61-5.96,5.73-5.904, WS 7.32- 8.67,8.44 and11.7, BS 6.73-9.04,9.67 and 12.81 and CW, 7.64-9.01,9.04 and 12.55\%. The soluble protein contents were in RS 0.57-0.896, 0.714-1.696, RH 0.42-0.46, 0.37 and 0.52 , WS 0.57$0.58,0.64$ and 0.714 , BS $0.58-0.68,0.69$ and 1.09 and CW $0.54-0.642,0.611$ and $0.971 \%$. The high crude and S. protein will likely increase the importance of the wastes as ruminant diet. But the fat content decreases constantly $1.13-1.62,1.5$ and 0.713 in RS, $0.483-0.650,0.55$ and 0.34 in RH, 4.0033.69,3.85 and 1.75 WS, reduction of fat in BS 1.63-1.63,1.55 and 0.99, and in CW 4.15-3.66,3.58 and $2.43 \%$ (Table 11 , lll \& V) (Shah, et al, 2004).

The fiber friction decreased significantly after the fungus growth as compared to the raw wastes. The decrease in fiber fraction could be due to the production of various enzymes during the vegetative and reproductive phases with lignocellulose degrading properties. The decreased in fiber content of the wastes were in RS 24.23, 21.67, 22.61 and 16.22, RH $34.86-33.59,32.313$ and 30.95, in WS 30.5128.52, 29.35 and 27.067, BS 39.29- 34.87 and 33.99-29.9, and in CW 65.02-63.55,61.64 and $61.36 \%$ (Table 11, 111 \& V).Similarly, the \% loss of lignin contents was in RS 34.38-32.57,32.93 and 47.86, RH 2.39-3.91, 2.39 and 14.79 \%, WS 18.44-27.25, 37.33 and 45.72, BS 5.34-16.10, 24.36 and 38.82 and CW 29.53-33.77,32.15 and 41.49\%. The solubilization of the lignin occurs during the vegetative phase and enzymes like laccase, manganese peroxidase and lignin peroxidase are secreted while cellulose degrading enzymes is secreted during reproductive phase (Table IV\& Vl) (Tamara, et al, 1995).

The reduction of hemicellulose content recorded for the fungus treated different agro wastes were, RS, 21.39-24.82, 21.48 and 33.21, RH 8.15-10.01,9.03 and 16.04, WS,13.74-16.29,18.05 and 27.66, BS 14.66-19.35, 21.453 and 26.91, CW $9.14-16.93,13.74$ and $37.82 \%$.(Table $\mathrm{lV} \& \mathrm{Vl}$ ) The \% of cellulose loss was in RS, 15.71-27.33,17.38 and 37.85, RH, 4.20- 6.54,7.14 and 10.65, WS, 15.9922.19, 23.27 and 29.03\%, in BS, 9.95-13.36, 11.00 and 30.52, and in CW 10.37- 15.68, 15. 31 and 31.95 (Table lV \& Vl).

To investigates the effects of acid and basic treatment of agro wastes on the growth of P. ostreatus mycelia are shown in Table V \& Vl. Higher mycelial growth and degradation activities observed in treated substrates as compared to untreated agro waste. Appreciable degradation was recorded in acid and base treated substrate (Table V \& Vl).

It was also found that acid and base treatment was most effective for the production of fruiting bodies. $1.25 \%$ acid and basic wash of the agro waste improved the fermentation process. 
Comparative Study on the Growth and Yield of Pleurotus Ostreatus Mushroom on Lignocellulosic by- Products

Table I. Differences between the biomass losses, number of fruit bodies and biological efficiencies of agricultural wastes.

\begin{tabular}{|l|l|l|l|}
\hline Treatment & Biomass loss & No. of fruit bodies & Biological efficiencies \\
\hline Rice straw & $\%$ & Mean & $\%$ \\
\hline Control & $29.79 \mathrm{~d}$ & $74 \mathrm{cde}$ & $25.61 \mathrm{abc}$ \\
\hline With chick pea & $51.70 \mathrm{a}$ & $113 \mathrm{a}$ & $32.69 \mathrm{a}$ \\
\hline Acid treated & $49.79 \mathrm{a}$ & $82 \mathrm{bcd}$ & $26.85 \mathrm{abc}$ \\
\hline Basic treated & $49.077 \mathrm{a}$ & $81 \mathrm{cde}$ & $26.66 \mathrm{abc}$ \\
\hline Rice husk & & & \\
\hline Control & $16.89 \mathrm{e}$ & $37 \mathrm{~g}$ & $9.51 \mathrm{~d}$ \\
\hline With chick pea & $30.00 \mathrm{~d}$ & $51 \mathrm{fg}$ & $15.04 \mathrm{~cd}$ \\
\hline Acid treated & $24.07 \mathrm{e}$ & $39 \mathrm{~g}$ & $12.33 \mathrm{~d}$ \\
\hline Basic treated & $22.63 \mathrm{e}$ & $46 \mathrm{fg}$ & $10.81 \mathrm{~d}$ \\
\hline Wheat straw & & & \\
\hline Control & $38.023 \mathrm{bc}$ & $59 \mathrm{ef}$ & $22.6 \mathrm{ab}$ \\
\hline With chick pea & $48.86 \mathrm{a}$ & $78 \mathrm{cde}$ & $28.60 \mathrm{ab}$ \\
\hline Acid treated & $46.86 \mathrm{a}$ & $68 \mathrm{de}$ & $25.81 \mathrm{ab}$ \\
\hline Basic treated & $47.423 \mathrm{a}$ & $66 \mathrm{def}$ & $26.09 \mathrm{bcd}$ \\
\hline Barley straw & & & \\
\hline Control & $30.00 \mathrm{~d}$ & $57 \mathrm{ef}$ & $21.63 \mathrm{abc}$ \\
\hline With chick pea & $35.34 \mathrm{~cd}$ & $77 \mathrm{cde}$ & $26.69 \mathrm{abc}$ \\
\hline Acid treated & $33.00 \mathrm{~cd}$ & $63 \mathrm{ef}$ & $23.97 \mathrm{abc}$ \\
\hline Basic treated & $33.33 \mathrm{~cd}$ & $64 \mathrm{def}$ & $18.06 \mathrm{abc}$ \\
\hline Cotton waste & & $72 \mathrm{de}$ & $25.78 \mathrm{abc}$ \\
\hline Control & $33.40 \mathrm{~d}$ & $113 \mathrm{a}$ & $32.05 \mathrm{a}$ \\
\hline With chick pea & $50.79 \mathrm{a}$ & $82 \mathrm{~b}$ & $26.04 \mathrm{abc}$ \\
\hline Acid treated & $48.26 \mathrm{a}$ & $\mathrm{afference}$ & \\
\hline
\end{tabular}

Mean with different letters in a column show significant difference $(P=0.05)$ as determined by DMR test.

Table II. Biodegradation of agricultural wastes by P.ostreatus.

\begin{tabular}{|l|l|l|l|l|l|l|l|l|}
\hline $\begin{array}{l}\text { P.ostreatus } \\
\text { Waste used }\end{array}$ & $\begin{array}{l}\mathrm{DM} \\
\%\end{array}$ & $\begin{array}{l}\mathrm{MC} \\
\%\end{array}$ & $\begin{array}{l}\text { Ash } \\
\%\end{array}$ & $\begin{array}{l}\text { Fat } \\
\%\end{array}$ & $\begin{array}{l}\mathrm{CP} \\
\%\end{array}$ & $\begin{array}{l}\text { SP } \\
\%\end{array}$ & $\begin{array}{l}\text { CF } \\
\%\end{array}$ & $\begin{array}{l}\text { NFE } \\
\%\end{array}$ \\
\hline Rice straw & $* *$ & $* *$ & $* * *$ & $*$ & $*$ & & $* * *$ & $* * *$ \\
\hline Non deg.Value & $8513 \mathrm{a}$ & $7.53 \mathrm{~b}$ & $19.00 \mathrm{~b}$ & $1.59 \mathrm{a}$ & $1.70 \mathrm{~b}$ & $0.55 \mathrm{a}$ & $25.64 \mathrm{c}$ & $52.07 \mathrm{a}$ \\
\hline Deg value & $81.31 \mathrm{bc}$ & $49.43 \mathrm{a}$ & $15.97 \mathrm{c}$ & $1.13 \mathrm{~b}$ & $7.07 \mathrm{a}$ & $0.572 \mathrm{a}$ & $24.22 \mathrm{~d}$ & $51.62 \mathrm{a}$ \\
\hline Rice Husk & $* *$ & $* * *$ & $*$ & & $* *$ & & $* * *$ & $* * *$ \\
\hline Non deg.Value & $83.07 \mathrm{ab}$ & $10.87 \mathrm{~b}$ & $25.30 \mathrm{a}$ & $0.54 \mathrm{~b}$ & $3.19 \mathrm{~b}$ & $0.347 \mathrm{a}$ & $36.18 \mathrm{a}$ & $34.78 \mathrm{c}$ \\
\hline Deg value & $77.83 \mathrm{c}$ & $39.93 \mathrm{~b}$ & $20.51 \mathrm{a}$ & $0.48 \mathrm{a}$ & $5.61 \mathrm{~b}$ & $0.418 \mathrm{a}$ & $34.86 \mathrm{~b}$ & $38.47 \mathrm{c}$ \\
\hline Wheat straw & $*$ & $* * *$ & & & & & $*$ & $*$ \\
\hline Non deg.Value & $88.16 \mathrm{a}$ & $6.24 \mathrm{~b}$ & $13.79 \mathrm{a}$ & $6.11 \mathrm{a}$ & $4.123 \mathrm{a}$ & $0.432 \mathrm{a}$ & $36.133 \mathrm{a}$ & $39.82 \mathrm{~b}$ \\
\hline Deg value & $83.53 \mathrm{~b}$ & $59.43 \mathrm{a}$ & $11.41 \mathrm{a}$ & $3.67 \mathrm{a}$ & $7.324 \mathrm{a}$ & $0.567 \mathrm{a}$ & $30.513 \mathrm{~b}$ & $47.09 \mathrm{a}$ \\
\hline Barley straw & $* *$ & $* * *$ & $*$ & $*$ & $*$ & $*$ & $* * *$ & $* * *$ \\
\hline Non deg. value & $89.37 \mathrm{~b}$ & $2.85 \mathrm{c}$ & $3.20 \mathrm{ab}$ & $2.45 \mathrm{ab}$ & $3.16 \mathrm{~b}$ & $0.29 \mathrm{ab}$ & $43.683 \mathrm{~b}$ & $47.48 \mathrm{a}$ \\
\hline Degrade. Value & $85.39 \mathrm{~b}$ & $55.74 \mathrm{~b}$ & $2.62 \mathrm{~b}$ & $1.63 \mathrm{a}$ & $6.734 \mathrm{a}$ & $0.58 \mathrm{a}$ & $39.293 \mathrm{c}$ & $49.06 \mathrm{a}$ \\
\hline Cotton waste & $* *$ & $* * *$ & & & & & & \\
\hline Non deg.Value & $93.21 \mathrm{a}$ & $3.09 \mathrm{c}$ & $5.71 \mathrm{a}$ & $4.11 \mathrm{a}$ & $3.65 \mathrm{~b}$ & $0.301 \mathrm{~b}$ & $67.35 \mathrm{a}$ & $17.86 \mathrm{~b}$ \\
\hline Deg value & $90.82 \mathrm{~b}$ & $56.16 \mathrm{a}$ & $3.68 \mathrm{ab}$ & $4.15 \mathrm{a}$ & $7.64 \mathrm{a}$ & $0.54 \mathrm{ab}$ & $65.02 \mathrm{a}$ & $19.51 \mathrm{~b}$ \\
\hline
\end{tabular}

Mean with different letters in a column show significant difference $(P=0.05)$ as determined by DMR test.

Table III. Effect of nitrogen (Chick pea powder) on the mycelial growth and degradation capacity of P.ostreatus.

\begin{tabular}{|l|l|l|l|l|l|l|l|l|}
\hline $\begin{array}{l}\text { Agricultural } \\
\text { Wastes }\end{array}$ & $\begin{array}{l}\text { DM } \\
\%\end{array}$ & $\begin{array}{l}\text { MC } \\
\%\end{array}$ & $\begin{array}{l}\text { Ash } \\
\%\end{array}$ & $\begin{array}{l}\text { Fat } \\
\%\end{array}$ & $\begin{array}{l}\text { CP } \\
\%\end{array}$ & $\begin{array}{l}\text { SP } \\
\%\end{array}$ & $\begin{array}{l}\text { CF } \\
\%\end{array}$ & $\begin{array}{l}\text { NFE } \\
\%\end{array}$ \\
\hline & $* * *$ & $* *$ & $* * *$ & $* *$ & $* *$ & $*$ & $* * *$ & $* * *$ \\
\hline Rice straw & $61.86 \mathrm{~d}$ & $60.74 \mathrm{a}$ & $13.64 \mathrm{a}$ & $0.71 \mathrm{c}$ & $12.47 \mathrm{a}$ & $1.69 \mathrm{a}$ & $16.22 \mathrm{e}$ & $57.41 \mathrm{~b}$ \\
\hline Rice husk & $71.87 \mathrm{c}$ & $49.08 \mathrm{~b}$ & $14.29 \mathrm{a}$ & $0.34 \mathrm{c}$ & $5.95 \mathrm{~b}$ & $0.52 \mathrm{~b}$ & $30.95 \mathrm{c}$ & $48.52 \mathrm{~b}$ \\
\hline Wheat straw & $78.40 \mathrm{~b}$ & $61.49 \mathrm{a}$ & $12.02 \mathrm{~b}$ & $1.75 \mathrm{ab}$ & $11.65 \mathrm{a}$ & $0.72 \mathrm{ab}$ & $27.07 \mathrm{~d}$ & $47.51 \mathrm{a}$ \\
\hline Barley straw & $79.51 \mathrm{~b}$ & $61.94 \mathrm{a}$ & $1.19 \mathrm{c}$ & $0.99 \mathrm{bc}$ & $12.81 \mathrm{a}$ & $1.09 \mathrm{ab}$ & $29.9 \mathrm{~b}$ & $54.71 \mathrm{~b}$ \\
\hline Cotton waste & $82.25 \mathrm{a}$ & $63.11 \mathrm{a}$ & $1.71 \mathrm{c}$ & $2.43 \mathrm{a}$ & $12.53 \mathrm{a}$ & $0.97 \mathrm{ab}$ & $61.36 \mathrm{a}$ & $21.94 \mathrm{c}$ \\
\hline
\end{tabular}

Mean with different letters in a column show significant difference $(P=0.05)$ as determined by DMR test. 
Table IV. Biodegradation of agricultural wastes and \% age losses of organic matters (\% differences of carbohydrates of different wastes after biodegradation)

\begin{tabular}{|l|l|l|l|l|l|l|}
\hline $\begin{array}{l}P . \text { Ostreatus Wastes Used. (\% } \\
\text { Value of degraded contents). }\end{array}$ & Cellulose & $\begin{array}{l}\text { Cellulose } \\
\text { loss\% }\end{array}$ & $\begin{array}{l}\text { Hemi- } \\
\text { cellulose }\end{array}$ & $\begin{array}{l}\text { Hemi Cellulose } \\
\text { loss\% }\end{array}$ & Lignin & $\begin{array}{l}\text { Lignin } \\
\text { loss\% }\end{array}$ \\
\hline Rice Straw & & & & & & \\
\hline Without N2 & 28.91 & $15.71 \mathrm{~d}$ & 19.20 & $21.39 \mathrm{~d}$ & 9.19 & $34.38 \mathrm{~d}$ \\
\hline With N2 & 21.32 & $37.85 \mathrm{~b}$ & 16.31 & $33.21 \mathrm{c}$ & 7.31 & $47.86 \mathrm{a}$ \\
\hline Rice husk & & & & & & \\
\hline Without N2 & 35.81 & $4.20 \mathrm{~g}$ & 13.16 & $8.15 \mathrm{f}$ & 34.01 & $2.38 \mathrm{f}$ \\
\hline With N2 & 32.88 & $10.65 \mathrm{e}$ & 11.99 & $16.04 \mathrm{e}$ & 30.04 & $14.79 \mathrm{e}$ \\
\hline Wheat straw & & & & & & \\
\hline Without N2 & 33.18 & $15.99 \mathrm{~d}$ & 33.16 & $13.74 \mathrm{~d}$ & 11.51 & $18.44 . \mathrm{e}$ \\
\hline With N2 & 28.03 & $29.03 \mathrm{bc}$ & 27.73 & $27.66 \mathrm{~b}$ & 7.66 & $45.72 \mathrm{e}$ \\
\hline Barley straw & & & & & & \\
\hline Without N2 & 36.69 & $9.95 \mathrm{f}$ & 20.45 & $14.66 \mathrm{e}$ & 11.03 & $5.34 \mathrm{e}$ \\
\hline With N2 & 28.32 & $30.51 \mathrm{c}$ & 17.52 & $26.91 \mathrm{~b}$ & 7.12 & $38.82 \mathrm{~d}$ \\
\hline Cotton wastes & & & & & & \\
\hline Without N2 & 49.11 & $10.37 \mathrm{f}$ & 11.15 & $9.14 \mathrm{~d}$ & 12.54 & $29.53 \mathrm{e}$ \\
\hline With N2 & 37.29 & $31.96 \mathrm{a}$ & 7.63 & $37.83 \mathrm{a}$ & 10.41 & $41.49 \mathrm{~b}$ \\
\hline
\end{tabular}

Mean with different letters in a column show significant difference $(P=0.05)$ as determined by DMR test.

Table V. Agricultural wastes treated with $1.25 \%$ acid and base.

\begin{tabular}{|c|c|c|c|c|c|c|c|c|}
\hline Agricultural Wastes & $\begin{array}{l}\mathrm{DM} \\
\%\end{array}$ & $\begin{array}{l}\mathrm{MC} \\
\%\end{array}$ & $\begin{array}{l}\text { Ash } \\
\%\end{array}$ & $\begin{array}{l}\text { Fat } \\
\%\end{array}$ & $\begin{array}{l}\mathrm{CP} \\
\%\end{array}$ & $\begin{array}{l}\text { SP } \\
\%\end{array}$ & $\begin{array}{l}\mathrm{CF} \\
\%\end{array}$ & $\begin{array}{l}\text { NFE } \\
\%\end{array}$ \\
\hline & $* * *$ & $* *$ & $* * *$ & $*$ & & & $* * *$ & $* * *$ \\
\hline Rice straw (Acid) & 79.21ab & $55.00 \mathrm{abc}$ & $16.42 \mathrm{a}$ & $1.62 b$ & $9.42 \mathrm{ab}$ & $0.89 \mathrm{a}$ & $21.67 \mathrm{de}$ & $50.87 a$ \\
\hline (Basic) & $79.827 c$ & $58.23 \mathrm{a}$ & $17.24 \mathrm{a}$ & $1.49 \mathrm{~b}$ & $8.46 a b$ & $0.71 \mathrm{a}$ & $21.61 \mathrm{e}$ & $50.1 .9 a$ \\
\hline Rice husk (Acid) & $76.05 \mathrm{bc}$ & $42.12 b c$ & $18.63 \mathrm{a}$ & $0.65 b$ & $5.96 b$ & $0.46 a$ & $33.59 \mathrm{~cd}$ & $41.17 b$ \\
\hline (Basic) & $74.73 \mathrm{bc}$ & $48.26 \mathrm{c}$ & $18.03 \mathrm{a}$ & $0.55 b$ & $5.73 b$ & $0.36 \mathrm{a}$ & $32.31 \mathrm{~cd}$ & $43.06 \mathrm{~b}$ \\
\hline Wheat straw (Acid) & $81.51 \mathrm{ab}$ & $62.093 \mathrm{a}$ & $10.63 b c$ & $4.49 \mathrm{a}$ & $8.67 \mathrm{ab}$ & $0.58 \mathrm{a}$ & $28.52 \mathrm{de}$ & $47.69 \mathrm{a}$ \\
\hline (Basic) & $82.26 \mathrm{ab}$ & $58.94 \mathrm{abc}$ & $9.073 b$ & $4.19 \mathrm{ab}$ & $8.443 \mathrm{ab}$ & $0.64 a$ & $29.35 \mathrm{de}$ & $48.943 \mathrm{a}$ \\
\hline Barley straw (Acid) & $84.08 \mathrm{ab}$ & 57.08abc & $1.82 \mathrm{c}$ & $1.63 \mathrm{ab}$ & $9.04 \mathrm{ab}$ & $0.68 \mathrm{a}$ & $34.87 \mathrm{~b}$ & $52.65 a$ \\
\hline (Basic) & $83.23 \mathrm{a}$ & $61.24 \mathrm{abc}$ & $1.84 \mathrm{c}$ & $1.55 \mathrm{ab}$ & $9.67 \mathrm{ab}$ & $0.69 \mathrm{a}$ & $33.99 b c$ & $52.88 \mathrm{a}$ \\
\hline Cotton waste (Acid) & $87.70 \mathrm{a}$ & $57.94 \mathrm{abc}$ & $3.84 \mathrm{c}$ & $3.66 \mathrm{ab}$ & $9.01 \mathrm{ab}$ & $0.64 a$ & $63.55 b$ & $17.99 \mathrm{a}$ \\
\hline (Basic) & 87.73 & $62.36 \mathrm{ab}$ & $4.12 \mathrm{c}$ & $3.58 \mathrm{ab}$ & $9.04 \mathrm{a}$ & $0.611 \mathrm{a}$ & $61.64 b$ & $22.29 \mathrm{a}$ \\
\hline
\end{tabular}

Mean with different letters in a column show significant difference $(P=0.05)$ as determined by DMR test.

Table VI. Biodegradation of acid and basic treated agro wastes. (\% differences of carbohydrates of different wastes after biodegradation)

\begin{tabular}{|r|l|l|l|l|l|l|}
\hline $\begin{array}{l}\text { Agricultural } \\
\text { waste }\end{array}$ & Cellulose & $\begin{array}{l}\text { Cellulose } \\
\text { loss\% }\end{array}$ & $\begin{array}{l}\text { Hemi- } \\
\text { cellulose }\end{array}$ & $\begin{array}{l}\text { Hemi Cellulose } \\
\text { loss\% }\end{array}$ & Lignin & $\begin{array}{l}\text { Lignin } \\
\text { loss\% }\end{array}$ \\
\hline Rice straw Acid & 24.93 & $\begin{array}{l}2734 \mathrm{a} \\
17.38 \mathrm{abc}\end{array}$ & $\begin{array}{l}18.36 \\
19.17\end{array}$ & $\begin{array}{l}24.82 \mathrm{a} \\
21.48 \mathrm{a}\end{array}$ & $\begin{array}{l}9.45 \\
9.39\end{array}$ & $\begin{array}{l}32.57 \mathrm{a} \\
32.93 \mathrm{a}\end{array}$ \\
\hline Basic & 28.34 & $6.54 \mathrm{c}$ & 13.03 & $10.02 \mathrm{a}$ & 33.483 & $3.91 \mathrm{~b}$ \\
Bice husk Acid & 34.95 & $7.14 \mathrm{c}$ & 12.99 & $9.03 \mathrm{a}$ & 33.66 & $2.39 \mathrm{~b}$ \\
\hline Wheat straw Acid & 34.49 & $22.19 \mathrm{ab}$ & 32.18 & $16.29 \mathrm{a}$ & 10.27 & $27.25 \mathrm{a}$ \\
Basic & 30.31 & $23.27 \mathrm{ab}$ & 31.50 & $18.05 \mathrm{a}$ & 8.85 & $37.33 \mathrm{a}$ \\
\hline Barley straw Acid & 35.31 & $13.36 \mathrm{bc}$ & 19.33 & $19.35 \mathrm{a}$ & 9.76 & $16.10 \mathrm{ab}$ \\
Basic & 36.27 & $11.01 \mathrm{bc}$ & 18.82 & $21.45 \mathrm{a}$ & 8.79 & $24.36 \mathrm{a}$ \\
\hline Cotton waste Acid & 46.19 & $15.68 \mathrm{abc}$ & 9.65 & $16.93 \mathrm{a}$ & 11.78 & $33.78 \mathrm{a}$ \\
Basic & 46.40 & $15.32 \mathrm{ab}$ & 10.58 & $13.74 \mathrm{a}$ & 12.07 & $32.15 \mathrm{a}$ \\
\hline
\end{tabular}

Mean with different letters in a column show significant difference $(P=0.05)$ as determined by DMR test. 


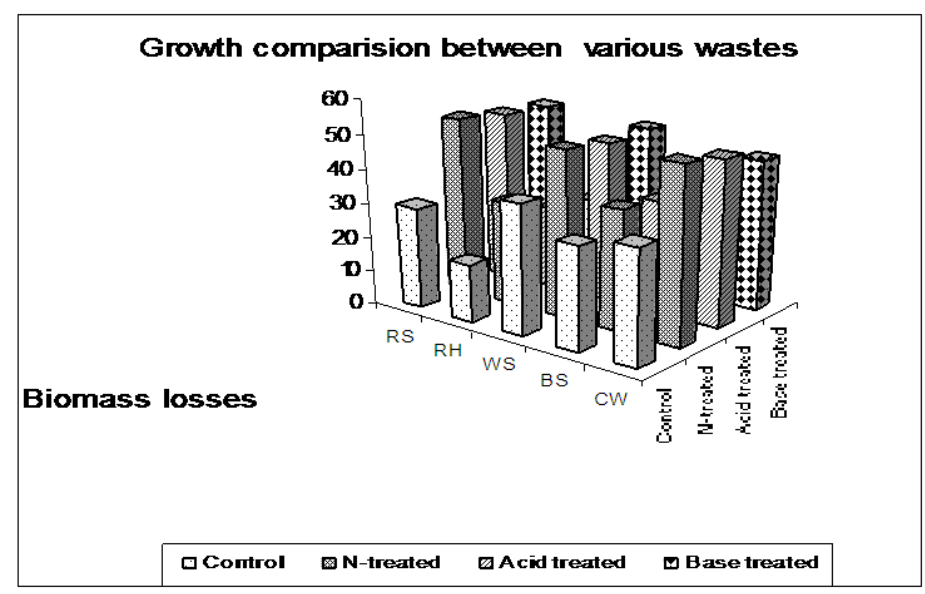

Fig1.

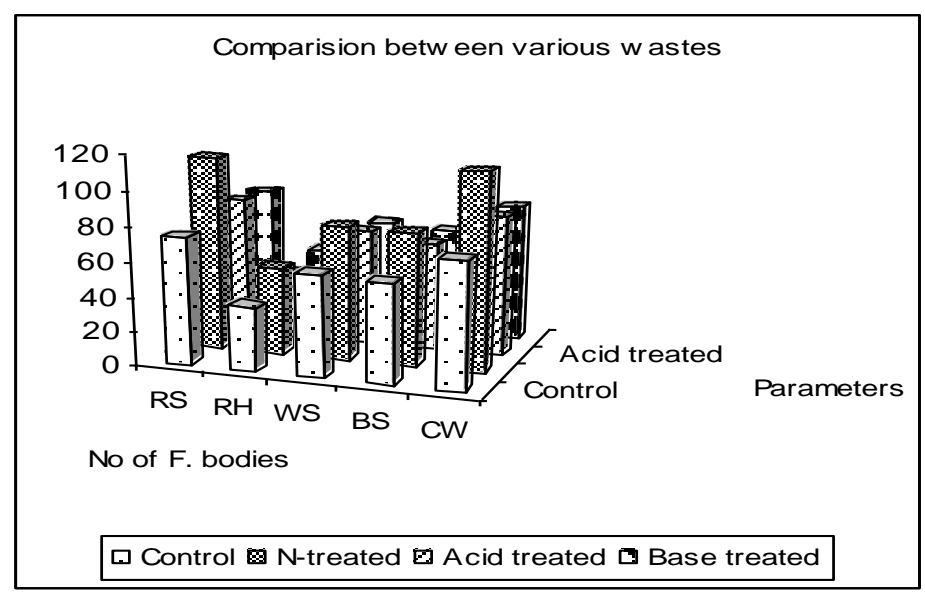

Fig2.

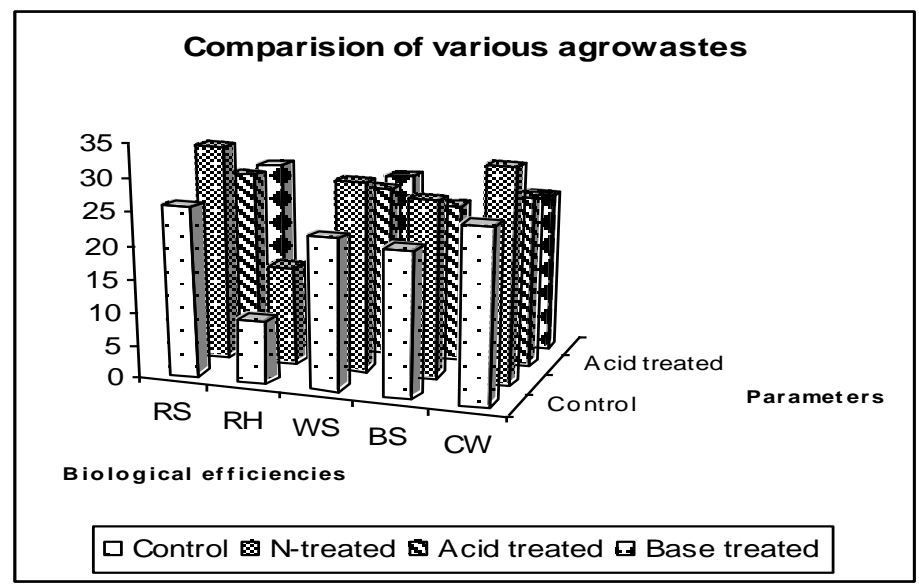

Fig3.

\section{REFERENCES}

[1] Abena O, Adjapong, Kwane D, Ansah, Faustina A and Henry O 2015. Maize residue as a viable substrate for farm scale cultivation of Oyster mushroom (Pleurotus ostreatus) Dept. Gen. Agri. School Appl. Sci.Tech. vol. 2015 Article ID 213251 1-6.

[2] ASTM Method 1961. American Society for Testing Materials and standard method of lignin in wood. 1106-56T pages 848.

[3] Belewu MA 2003. Nutritional qualities of corn cobs and waste paper incubated with edible mushroom (Pleurotus sajor caju). Nig. J. Anim. Prod. Vol. 30 (1): 20-25.

[4] Bhatti MI, Jiskani MM, Wagan KH, Pathan MA and Magsi MR 2007. "Growth development and yield of oyster mushroom, Pleurotus ostreatus (jacq.Ex. Fr.) Kummer as affected by different spawn rates," Pak. J. Bot. 39: 2685-2692. 
[5] Chang ST and Miles PG 1988. Edible Mushroom and their cultivation. CRC press, Inc. Boca Raton, Florida U.S.A.27:83-88. Chow.

[6] Fasidi IO 1996. Studies on Volvariella esculenta (mass) singer: Cultivation on Agricultural wastes and proximate composition of stored mushrooms. Food Chem., 55 (2): 161-163.

[7] Goering HK and Van Soest PJ 1970. Forage fibre analysis (Apparatus, Reagents, and Procedures and some application). Agricultural hand book No. 379. Agricultural Research Service, United state Department of Agriculture.

[8] Hami H 1990. Cultivation of oyster mushroom. (Pleurotus spp.) On saw dust of different woods M.Sc thesis Department of plant pathology, University of Agriculture, Faisalabad, Pakistan.

[9] Hassan S, Mohammad AY and Kiramat K 2011. "Cultivation of Oyster mushroom (Pleurotus ostreatus) Jacq. P Kumm) in two different agro ecological zones of Pakistan.” Afri. J. Biotech. Vol. 10: 183-188.

[10] Jacqueline E W, Visser B 1996. Biotechnology: Building on Farmers, knowledge: In Assessing the potential edited by joske Bunders, Biertus Haverkort and Wim Hiemstra. Published by Macmillan Education Ltd. London, Basingstroke.

[11] Khare KB, Mutuku JM, Achwania OS, and. Otaye DO 2010. "Production of two oyster mushrooms Pleurotus sajor caju and P. florida on supplemented and un-supplemented substrates." Int.J.Agri.Appli.edSci.: 6, 4-11.

[12] Kausar T, Bajwa R 2005. Incorporation of Button Mushrooms in Pakistani Dishes. w Pak. J. Sci. Ind. Res. 48 (6): 417-421.

[13] Kurschner K and Hank A. 1930. Determination of cellulose. Z.Untersuch. Lebnsm; 59: 448- 485.

[14] Manson JC, Sims PGG, Broad P 1989. Biological routes to improve digestibility of animal feeds In: Biotechnology in livestock in developing countries. Edited by Hunter, A.G. Proceeding of an International Conference on the Application of Biotechnology to livestock in developing countries. Univ. of Edinburgh. Organized by the staff of the Center for Tropical Veterinary Medicine.

[15] Markham R 1942. A steam distillation apparatus suitable for Microkjeldahl analysis. Biochem. J. 36: $760-791$.

[16] Mata G, Hernandez DM, Andreu 2005. Changes in lignocelluloytic enzyme activities in six Pleurotus spp.strains cultivated on coffee pulp in confrontation with Trichoderma spp.World. J. Microb. Biotechnol. 21 (2): 143-150.

[17] Muhammad SN, Muhammad A A, Sajid A, Hasan S, Rizwan L and Muhammad S 2014. Growth and yield performance of oyster mushroom on different substrates. Mycopath 12(1): 9-15

[18] Oei P 2003. Mushroom cultivation, appropriate technology for mushroom growers. Backhugs Publishers, Leiden. The Netherlands. Sompson Ruktahi S, Uthai W, Chenkahia S (2004).

[19] Rana I, Kanojiya SA, Sandhu SS, 2007. Effect of waste organic substrates supplemented with mango leaf aqueous extract on the mycelial growth of Pleurotus sajor-caju and Pleurotus florida. J. Pure Appl. Microbiol., 1: 307-312. Rossi

[20] Shah ZA, Ashraf M, Ishtiaq M 2004. Comparative study on cultivation and yield performance of Oyster mushroom (Pleurotus ostreatus) on different substrates (Wheat straw, leaves, saw dust). Pak. J. Nut. 3(3): 158-160.

[21] Steel RGD and Torrie JH 1980. Principle and Procedure of Statistics. McGraw- Hill Publishers, London, U.K. 481.

[22] Tamara V, Mika K and Annele H 1995. Lignin peroxidase, Manganese peroxidases and other ligninolytic enzymes produced by phlebia radiate during solid state fermentation of wheat straw. Appl. Envi. Micro. 3515-3520.

[23] Wenjie Y, Feng LG and Zhengjie W 2013. Yield and size of oyster mushroom grown on rice and wheat straw basal substrate supplemented with cotton seed hull. Saudi J. Biol. Sci. 20(4): 333338. 